\title{
Legal aspects of the moratorium on bankruptcy as an innovative trend in business support in a pandemic.
}

\author{
Ekaterina Sapozhnikova ${ }^{1, *}$ \\ ${ }^{1}$ Don State Technical University, 344003, Gagarin sq., 1, Rostov-on-Don, Russia
}

\begin{abstract}
At the beginning of 2020, a difficult epidemiological situation developed in Russia against the background of the development of the Covid-19 pandemic. This situation had an extremely negative impact on the country's economy. The government has developed anti-crisis measures aimed at supporting economic entities in the most affected sectors of the economy. One of the measures to overcome the crisis was the transformation of legislation in the field of bankruptcy.
\end{abstract}

\section{Introduction}

The result of the anti-crisis measures in the Russian Federation was the introduction by the Federal Law of 01.04.2020 No. 98-FZ "On Amendments to Certain Legislative Acts of the Russian Federation on the Prevention and Elimination of Emergencies" of amendments to the Federal Law of 26.10.2002 No. 127-FZ " On insolvency (bankruptcy) "(hereinafter referred to as the Bankruptcy Law).

A completely new article 9.1 "Moratorium on the initiation of bankruptcy cases" has appeared in the above law. This rule allows the government to introduce a moratorium on the initiation of bankruptcy cases against debtors on the basis of the formation of the necessary groups of OKVED, as well as certain categories of persons.

The moratorium came into effect on April 6. Initially, the moratorium was introduced until October 6, 2020, but the law allows the government to extend it for any period.

The moratorium on bankruptcy helps business a lot: it's no secret that big business cannot do without loans and leases, and if now the main task for such companies is to preserve jobs, then payments on such loans will not be made on time. This is where the moratorium comes into force: it interferes with the liquidation of an enterprise in a situation when it continues to accumulate loans, but at the same time it cannot work [1].

Regardless of whether a company is subject to a moratorium or not, the restrictions imposed by themselves can only delay bankruptcy if the measures proposed by the authorities to support business in a pandemic, as well as the anti-crisis plans of the companies themselves, are insufficient to overcome the consequences of the crisis in the coming months [2-3].

*Corresponding author : vladimirovnale95@mail.ru 
A moratorium on bankruptcy, extended, along with other measures, to an insignificant list of enterprises, cannot prevent a large-scale recession. While there is still hope for more support, entrepreneurs seem to have to rely on themselves again. The moratorium is a guarantee precisely for conscientious persons that they will be given the opportunity to overcome the crisis.

In the conditions of non-working days announced by the President of the Russian Federation with the preservation of wages at the expense of the employer, as well as only postponed but not canceled tax obligations, this moratorium will not lead to significant business support and a decrease in the number of bankruptcies of companies and individual entrepreneurs after the end of the moratorium. Therefore, the record for the number of bankruptcies is still ahead [4].

An analysis of these changes made to the Bankruptcy Law in the context of the existing pandemic, in fact, testifies to the introduction by the legislator of another rehabilitation procedure applied before the initiation of bankruptcy proceedings and, according to the legislator, allowing the organization to overcome temporary financial difficulties during the moratorium [5].

\section{Materials and methods}

Among the negative consequences of the imposed moratorium, which, unfortunately, cannot be avoided, it should be noted, first of all, the possibility of abuse of the granted preference.

Let's say an organization is on the list of companies most affected by the pandemic, and, accordingly, falls under a moratorium. But the signs of bankruptcy for this company have arisen for a long time, and the beneficiaries of the business expected the initiation of bankruptcy proceedings by the creditors. In such a situation, unscrupulous persons have a real and long-term opportunity to prepare for bankruptcy: withdraw assets (their own and business), transfer the business to another company, create or increase friendly accounts payable, etc.

Moreover, even if we take into account that there is no abuse by business and is not expected, the introduction of an unconditional moratorium on a number of organizations included in the list, without examining the period of occurrence and the reasons for the debtor's insolvency, which, perhaps, do not depend on the pandemic, testifies to protect the interests of debtors, but not creditors[6,7,8].

But the likelihood of the use of bankruptcy innovations by unscrupulous business entities is quite high. There are already examples of this. So the moratorium on bankruptcy was used by one travel company, which in 2018 was involved in a high-profile scandal in the travel industry.

In December 2018, due to the debts of the tour operator, more than 2 thousand tourists from Russia were stuck on the island of Hainan. The tour operator, which at that time was operating under the Pearl River brand, owed IrAvia about 2 million US dollars. Flights were suspended, and more than 2, 4 thousand tourists could not get home. The Tourist Assistance Association was responsible for the return of tourists from China, spending about 70 million rubles from the reserve fund for this purpose [9].

A criminal case was initiated against the travel agency on December 10, 2018. Subsequently, by Order of the Federal Tourism Agency of December 12, 2018 No. 502-Pr18, Travel Designers LLC (TIN 7704363 557) and Hercules Travel LLC (TIN 7840462 444) were excluded from the unified federal register of tour operators. under the general brand "Pearl River".

At the end of December 2018, it turned out that 5.42 thousand clients of the tour operator who had already bought vouchers would not be able to go on vacation. 
With respect to the above-described defendants, the Moscow Arbitration Court on April 21, 2020 received a claim from four individuals for the bankruptcy of Travel Designers LLC. The court decided to return the claim, since the debtor is subject to a measure of protection in the form of a moratorium on bankruptcy. It should be noted that in relation to Travel Designers LLC, there are 1,200 enforcement proceedings in the database of the Federal Bailiff Service. In most cases, we are talking about foreclosures of a property nature in favor of individuals and legal entities. Probably, through the court, former clients of the company are still trying to reimburse the cost of vouchers, material and moral damage from a failed vacation [10].

The economic crisis against the backdrop of the pandemic has led to a wave of measures to temporarily liberalize bankruptcy laws not only in Russia, but also in the world. Many countries have imposed moratoriums on creditors filing bankruptcy filings, or at least increased the minimum amount of debt, and also relaxed the requirements for loans that shareholders give to their companies.

The most drastic option is seen in India, where a complete ban on filing for bankruptcy was introduced, even if the insolvency of the company is not related to the pandemic. This approach, according to experts, is unlikely to solve the problem, since the "powerful wave of bankruptcies" is only postponed.

However, some countries did not dare to take such measures and only raised the minimum debt threshold at which creditors can go to court - for example, in Singapore, this amount increased from $\$ 10$ thousand to $\$ 100$ thousand. However, such a measure can hardly be considered effective - it does not protect corporations from relatively large creditors.

For the management of the debtor company, many countries have also provided for an exemption from the obligation to file for their own bankruptcy, for example, in France, Germany, Italy, Spain, Austria, the Czech Republic. The effectiveness of such a measure primarily depends on its duration: if the freeze is introduced for too short a period, then "instead of recovering, many companies may face a slow death." Among the examples of the short-term freeze of the obligation to file a bankruptcy petition for his company is Spain, where such a measure was originally introduced only until March 29, but then it was extended until the end of the year. A longer period is provided in Germany - until March 31, 2021.

The "curative" effect of another measure depends on the period of validity - the suspension of the principle of "recapitalization or liquidation", which operates in many European countries. This rule was frozen, for example, by the authorities of France, Italy and Spain. So, Rome suspended it until the end of the year, which, according to experts, may be insufficient, since losses incurred during the current year will be reflected in the annual financial statements, which will only be presented in 2021.

To stimulate financial support for companies from their shareholders, foreign governments have also abolished the rule on the subordination of loans that shareholders can provide to the enterprise. So, as a general rule, in the event of bankruptcy of companies, such loans are returned to shareholders only after the claims of other creditors are repaid as a result, they often receive nothing. Now, for example, in Germany, the claims of shareholders who issued such loans before September 30, 2020 are considered in bankruptcy cases on a par with the usual claims of creditors [11-12].

In Germany, a temporary ban on bankruptcy at the request of the lender has been introduced for all companies, provided that their financial losses are associated with the COVID-19 pandemic and there is a possibility of restoring solvency, which is confirmed by the fact that as of 12/31/2019 the company still had enough means to prevent bankruptcy. At the same time, German law allows any transactions to be made during the moratorium, as long as they are aimed at maintaining the debtor's solvency. 
If a temporary ban on the initiation of bankruptcy proceedings is carried out at the request of the creditor, then it is introduced in relation to all companies whose signs of insolvency arose after March 1, 2020.

In case of initiation of bankruptcy by the debtor, the moratorium is valid for the period from March 1 to September 30, 2020. This period can be extended until March 31, 2021. If the initiator is the creditor, then the moratorium is valid from March 1 to May 30, 2020. Perhaps German lawmakers also will be extended.

The difference between the German moratorium on bankruptcy and the Russian one is that in Germany the legislator has extended this norm to all enterprises of any sectors of the economy, regardless of whether they are backbone or not.

Consider the actions of US legislators to support business in modern realities. In response to the COVID-19 pandemic in the United States, changes have been made to the US Bankruptcy Code and Small Business Reorganization Act of 2019 (SBRA). For a year, the amount of debt increases (from $\$ 2.7$ million to $\$ 7.5$ million), at which small businesses will be able to apply for bankruptcy proceedings in accordance with the new subsection V of Chapter 11 of the US Bankruptcy Code. This will allow debtors to retain greater control over the business, it is easier to approve the reorganization plan, and reduce the time and cost of bankruptcy proceedings [13].

Consumers facing financial difficulties as a result of the pandemic will be able to push for changes to their previously approved reorganization plan, including extending their payments for up to seven years.

The study of measures taken by the countries of the Asia-Pacific region to support entrepreneurship in the era of coronavirus deserves special attention. A number of countries in the Asia-Pacific region are also implementing measures aimed at preventing massive bankruptcies during a pandemic. For example, in India, the minimum amount of debt for initiating bankruptcy of enterprises was increased by 100 times - to 10 million Indian rupees (about $\$ 130$ thousand), in Singapore - to an amount equivalent to $\$ 70$ thousand.

The experience of dealing with massive bankruptcies in Australia in connection with the pandemic is also noteworthy. In this country, the minimum threshold for filing for bankruptcy has been increased ten times for six months (up to 20 thousand Australian dollars). The time limit for responding to bankruptcy claims of creditors and the period of temporary protection from debt collection, during which the debtor's bankruptcy cannot be initiated, increased from 21 days to six months.

Thus, a moratorium has been established for creditors on filing an application for declaring a debtor bankrupt. When the creditor submits such an application, the court must return it. For the duration of the moratorium, the deadline for filing bankruptcy petitions will be suspended (for the omission of which, for example, the head of the organization is liable for subsidiary purposes). So, the course of the term for the debtor (this applies to both individuals and legal entities), who is obliged to submit an application within 1 month after he discovers objective signs of insolvency, is suspended [14].

On September 7, 2020, Australian Federal Treasurer Josh Friedenberg announced the extension of the interim insolvency and bankruptcy protection rules until the end of 2020.

According to the rules, which were first introduced in March and expire on September 30 , lenders cannot issue bankruptcy notices to businesses for debts below A \$20,000 (S \$ 19,863).

The deadline for notifying creditors of debt settlement action could also be extended, allowing many firms to continue trading without paying rent, taxes or loans.

These changes will help prevent a new wave of setbacks before businesses have a chance to recover. 
Australia's \$ 2 trillion economy entered its first recession in nearly 30 years in early September 2020 after stringent isolation measures to contain the spread of the virus wreaked havoc on its economy.

More than a million people have lost their jobs since March, when Australia closed entire sectors of the economy, affecting demand and private sector investment.

To cushion the blow from the impact of the virus, Australia has rolled out over A $\$ 300$ billion in stimulus packages, including a payroll subsidy scheme that has allowed hard-hit businesses to retain employees.

\section{Results}

The amendments to the legislation of the Russian Federation imply special rules for certain categories of debtors. The list of such debtors was formed on the basis of their OKVED (All-Russian Classifier of Economic Activities) as of March 1, 2020. Changes made to OKVED after this date will not allow the use of the moratorium. The law allows a company included in this list to refuse to participate in the moratorium by publishing a corresponding message on the unified federal register of bankruptcy information.

The Federal Tax Service has developed an appropriate list of codes for the All-Russian Classifier of Economic Activities and posted on its portal a list of organizations subject to the moratorium. To determine the category of subjects falling under the new article, a new service was launched on the website of the Federal Tax Service https://service.nalog.ru/covid/, which allows you to receive information about persons classified as the industries most affected by coronavirus infection ...

Organizations that can take advantage of the bankruptcy moratorium include companies operating in the field of air transportation, entertainment, tourism, organizing exhibitions and providing personal services to the population, sports and sanatorium-resort organizations, catering, and hotel business.

Despite the fact that this list includes almost 1.3 million companies and individual entrepreneurs, the sphere of activity of large, medium and small businesses is many times wider than those that fell under the corresponding moratorium. Such spheres of activity as transport, rent, construction, education, non-domestic services and many other industries are affected. It should also be noted that the bankruptcy moratorium does not apply to individuals [15].

The number of decisions on declaring companies bankrupt decreased $(-26 \%)$ when comparing the first half of 2020 and 2019. The indicator decreased from 6,083 units to 4,502 .

In the second quarter of this year, there was a significant decrease in the indicator by $39.8 \%$ (to 1895 ), in the first - by $11.2 \%$ (to 2607 ).

In June, growth accelerated, and the courts adopted a $30.5 \%$ increase in bankruptcy rulings (+963 units).

The head of "Fedresurs" recalled that the main reason for the changed statistics is a moratorium on bankruptcy. Some of the procedures were postponed because of this. The moratorium applies to 2 million companies and individual entrepreneurs, and only 450 entities refused it, which was announced on the EFRSB.

The decrease in the number of company bankruptcies is also due to the fact that the courts worked in a limited mode. Positive statistics reflect the situation in the economy about a year ago, when everything was more prosperous (Table 1).

According to the current Bankruptcy Law, the only creditor entitled to file a bankruptcy petition of the debtor with the court without prior notification of such intention is the authorized body. 
Table 1. Top 10 regions of the Russian Federation with the highest number of bankruptcies

\begin{tabular}{|c|c|c|c|}
\hline $\begin{array}{c}\text { Region in the } \\
\text { Russian Federation }\end{array}$ & $\begin{array}{c}\text { January to June } \\
\mathbf{2 0 1 9}\end{array}$ & $\begin{array}{c}\text { January to June } \\
\mathbf{2 0 2 0}\end{array}$ & Accretion \\
\hline Moscow & 1244 & 852 & $-31,5 \%$ \\
\hline Moscow region & 356 & 309 & $-13,2 \%$ \\
\hline St. Petersburg & 407 & 293 & $-28,0 \%$ \\
\hline Sverdlovsk region & 205 & 152 & $-25,9 \%$ \\
\hline $\begin{array}{c}\text { Republic of } \\
\text { Tatarstan }\end{array}$ & 174 & 141 & $-19,0 \%$ \\
\hline Novosibirsk region & 189 & 137 & $-27,5 \%$ \\
\hline Krasnodar region & 165 & 123 & $-25,5 \%$ \\
\hline Rostov region & 130 & 91 & $-30,0 \%$ \\
\hline Rostov region & 98 & 91 & $-7,1 \%$ \\
\hline Rostov region & 50 & 81 & $62,0 \%$ \\
\hline
\end{tabular}

The most prosperous regions are: the Tyva Republic, the Chukotka Autonomous Okrug, the Chita Region, and other territories, including the city of Baikonur, the Nenets Autonomous Okrug. In these entities, not a single approved decision to recognize the insolvency of any company was recorded.

"The decrease in the number of bankruptcies among companies is largely due to the moratorium on bankruptcy, as well as to the fact that they were in the process of accepting new circumstances and assessing their financial situation. But it is obvious that these numbers will change at the end of the year and we will see a completely different picture. The wave of bankruptcies in the business segment will begin at the end of the year, when the moratorium has already expired, all negotiations on the lease of office or retail space will be held and when the time comes for companies to realize their own financial prospects. Restricting business activity for more than two months will not pass without leaving a trace for either citizens or businesses.

Thus, in order to equalize the rights of the authorized body and other creditors of the debtor to initiate bankruptcy proceedings and to declare a candidate for the arbitration manager, the legislator quite rightly provided for the provision that after the expiration of the moratorium, the right to appeal to the arbitration court arises from the authorized body no earlier than than 15 calendar days after the expiration of the moratorium;

What aspects are spelled out in the new legislation:

- for the duration of the moratorium, the obligation of the debtor to apply for bankruptcy is suspended;

- there are a number of consequences provided for the introduction of the observation procedure;

- foreclosure on mortgaged property is not allowed, including out of court;

- the enforcement proceedings on property foreclosures for claims arising before the introduction of the moratorium are suspended (this does not remove the arrests on the debtor's property and other restrictions on the disposal of the debtor's property imposed during the enforcement proceedings).

This law also provides that the periods of suspicious transactions specified in Art. 61.2 and 61.3 of the Bankruptcy Law are calculated from the date of the imposition of the moratorium and include the corresponding period before the imposition of the moratorium and the period of the moratorium. This rule will apply to bankruptcies filed within three months after the end of the moratorium. 
At the same time, transactions made during the moratorium on the transfer of property and the assumption of obligations or obligations (except for those committed in the ordinary economic activity carried out by the debtor, if the price of the property transferred under one or several interrelated transactions, or the amount of the assumed obligations or obligations are not exceeds one percent of the value of the debtor's assets, determined on the basis of the debtor's financial statements for the last reporting period as of the date of the moratorium).

\section{Conclusions}

Note that most of the wording of Art. 9.1 of the Bankruptcy Law is too specific and does not allow for broad interpretation. But there are many questions that are not reflected in the law: subsidiary liability of the persons controlling the debtor; inclusion of a moratorium period in the limitation period for challenging void transactions in bankruptcy proceedings; the functioning of debtors who formally fall under the moratorium, but have signs of bankruptcy long before its introduction and many other issues.

In the context of the economic crisis, such a measure is not the best way out of the situation. Neither creditors, nor the debtors themselves will be able to get quick and effective justice, because the courts will wait for the publication of the position of the Supreme Court of the Russian Federation or at least the district court on many issues unregulated by law.

\section{References}

1. D. He, K. Yu, J. Wu, Journal of management analytics (2020) doi: 10.1080/23270012.2020.1715272.

2. K. Chen, H. Y. Wong, M. C. Chiu, Y. H. Shin, Siam journal on financial mathematics, 10, 977-1005 (2019) doi : 10.1137/19M124681X.

3. L. V. Sakharova, S. V. Rogozhin, A. N. Kuzminov, Studies in systems, decision and control, 282, 113-124 (2020) doi : 10.1007/978-3-030-44703-8_13.

4. I. A. Kiseleva, V. I. Kuznetsov, N. A. Sadovnikova, A. V. Pikalov, A. A. Dolgaya, Journal of critical reviews, 9, 1037-1042 (2020) doi : 10.31838/jcr.07.09.191.

5. B. Dietzenbacher, P. Borm, A. Estevez-Fernandez, Review of economic design, 24, 101-122 (2020) doi: 10.1007/s10058-019-00227-x.

6. Y. Shi, X. Li, Intangible capital, 15, 114-127 (2019) doi: 10.3926/ic.1354

7. W. C. Lin, Y. H. Lu, C. F. Tsai, Expert systems, 36, e12335 (2019) doi : 10.1111/exsy. 12335

8. R. Tkhagapso, M. Kuter, Advances in intelligent systems and computing, 850, 296-305 (2019) doi : 10.1007/978-3-030-02351-5_34

9. M. Kovacova, T. Kliestik, P. Kubala, K. Valaskova, M. M. Radišić, J. Borocki, Polish journal of management studies, 18, 167-179 (2018) doi : 10.17512/pjms.2018.18.1.13

10. S. A. Gorbatkov, F. S. Rastegaeva, S. A. Farkhieva, T. V. Nakonechnaya, T. N. Shashkova, Humanities and social sciences reviews, 3, 604-611 (2019) doi : 10.18510/hssr.2019.7391.

11. A. Dhawan, L. Ma, M. H. Kim, Effect of corporate tax avoidance activities on firm bankruptcy risk, 16, doi: 10.1016/j.jcae.2020.100187

12. N. Stef, S. Dimelis, Bankruptcy regime and the banking system, 87 doi: 10.1016/j.econmod.2019.12.012 
13. L. Bolaños, J. Gifford, J. Y. Kweun, Bankruptcy policy and surface transportation public-private partnerships: A comparative analysis of the U.S. and Europe, 7 doi: 10.1016/j.cstp.2019.04.003

14. H. Sona, C. Hyun, D. Phan, H. J. Hwang, Data analytic approach for bankruptcy prediction, 138 doi: 10.1016/j.eswa.2019.07.033

15. Y. Shi, X. Li, Heliyon, 5, 2405-8440 (2019) doi : 10.1016/j.heliyon.2019.e02997 